\title{
Transglutaminase from UV Mutated Bacillus cereus NRC215: Production, Purification, and Characterization
}

\author{
Osama Ibrahim ${ }^{1 \mathbb{D}}$, Pawel Glibowski ${ }^{2 \mathbb{D}}$, Rasha G. Salim ${ }^{3, * \mathbb{D}}$, Ghada M. El-Sayed ${ }^{3 \mathbb{D}}$ \\ 1 Dairy Science Department, National Research Centre, Dokki, Cairo, Egypt; osama_nrc@ @otmail.com (O.I.); \\ 2 Department of Biotechnology, Microbiology and Human Nutrition, University of Life Sciences in Lublin, Skromna 8, 20- \\ 704 Lublin, Poland; pawel.glibowski@up.lublin.pl (P.G.); \\ 3 Microbial genetics Department, National Research Centre, Dokki, Cairo, Egypt; rasha_gomma@yahoo.com (R.S.); \\ ghada.khalefa@yahoo.com (G.E.); \\ * Correspondence: rasha_gomma@yahoo.com (R.S.);
}

Scopus Author ID 57190883259

Received: 10.08.2021; Revised: 15.09.2021; Accepted: 18.09.2021; Published: 22.10.2021

\begin{abstract}
Transglutaminase (EC 2.3.2.13, TGase) recorded the highest activity $(0.101 \mathrm{U} / \mathrm{ml})$ in bacterial isolate NRC215. 16S rRNA sequencing revealed that NRC215 was identified as Bacillus cereus NRC215 under accession number MT229271 in the NCBI database. UV irradiation was employed to improve TGase production. Five rifampin (RIF) resistant mutants were only isolated from UV-treated Bacillus cereus NRC215 for three minutes. The best mutant, BCrif5, exhibiting induced rifampin resistance, gave TGase with higher activity $(0.148 \mathrm{U} / \mathrm{ml})$. The ISSR PCR technique was employed to detect these new rearrangements resulting from UV mutagenesis between the wild-type strain and its mutants. Moreover, TGase has been purified by three-step procedures resulting in a recovery of 28 and $34.63 \%$ for wild and BCrif5 strains, respectively. The optimal purified TGase activity was exhibited at $\mathrm{pH} 7$ for wild strain while the mutant $\mathrm{BCrif5}$ at $\mathrm{pH} 5.0$ and $40{ }^{\circ} \mathrm{C}$ for both wild and BCrif5 strains. Bacillus cereus NRC215 TGase was activated by $\mathrm{Ba}^{+2}(102.50$ and $107.06 \%)$, while it was inhibited by $\mathrm{Cu}^{+2}(30 \%$ and $22.35 \%)$ for wild and BCrif5 strains, respectively. It could be concluded that Bacillus cereus NRC215 is a promising strain for TGase production, which is beneficial as a food additive.
\end{abstract}

Keywords: transglutaminase; characterization; purification; 16s rDNA; UV mutagenesis; ISSR.

(C) 2021 by the authors. This article is an open-access article distributed under the terms and conditions of the Creative Commons Attribution (CC BY) license (https://creativecommons.org/licenses/by/4.0/).

\section{Introduction}

Transglutaminase (EC 2.3.2.13, TGase) is a class of hydrolases enzymes that catalyzes an acyl transfer reaction using peptide-bond glutamine residues as acyl donors and several primary amines as acceptors such as $\varepsilon$-amino groups of the protein-bound lysine residues to form intra- and inter-molecular $\varepsilon$ - $(\gamma$-Glu)-Lys isopeptide bonds [1,2].

TGase is widely used in the cross-linking of various food proteins, such as caseins and whey proteins, which improve food products' functional properties [3-7]. In addition, TGase is used in biomaterial cross-linking [8], protein immobilization [9], and enzymatic protein modification [10].

TGase is found in animal and plant tissues [11-14]. Also, Streptoverticillium mobaraensis the first strain recorded by Ando et al. (1989) [15] to produce TGase, which has several functions in the microbial cell, including cell growth, elongation, cell division, the extension of hyphae, and formation of spore coat [16]. 
Microorganisms usually produce valuable products, such as enzymes, in required amounts to benefit; thus, they tend not to overproduce their metabolites. Programs of strain improvement for producing a high titer are usually the desired goals. Genetics has had a long history of contributing to the production of microbial products, especially microbial enzymes [17]. A successful relationship between mutational genetics and industrial microbiology has been reported. A great number of studies have been reported for using the strain improvement process through mutations for producing various industrial enzymes like chitinase, lipase, cellulase, glucoamylase, and protease [18,19].

Modification and improvement of the strains are achieved by treating them with various physical such as UV or chemical agents called mutagens. The literature provides many examples of activation of silent or weakly expressed gene clusters coding for secondary metabolites by RIF resistant mutations in B. subtilis and Actinomycetes [20,21]; it drives us to suppose that bacterial gene expression may be altered dramatically by ribosomal proteins or rRNA modifying. Thus, the present work aimed to develop "ribosome engineering" to take full advantage of bacterial abilities. As certain extracellular enzymes such as TGase are known to be produced during the late growth phase, it seemed plausible that the synthesis of this enzyme might be enhanced by potential rifampicin-resistant mutants. Also, inter simple sequence repeat polymerase chain reaction (ISSR-PCR) is a superlative and powerful technique for genetic diversity analysis. According to Baysal et al. (2011) [22], ISSR-PCR as a molecular marker is believed to be a fast and low-cost tool for several applications concerning the genetic similarity classification among species. ISSR-PCR primers have amplified the variable region among the complementary sequences between two neighboring microsatellites that were copied during evolution [23]; therefore, it is a powerful choice to discuss new DNA rearrangements in bacterial mutants.

TGase limited sources and hard downstream procedures compelled the researchers to search for other alternative available microbial sources due to easy large-scale continuous production, short production time, and low cost; as well as interesting studies have been directed towards the improvement of bacterial TGase by classical mutagenesis are still limited.

Thus, the present study aimed to screen different bacterial strains for TGase production to improve the production of TGase from the selected strain by UV mutagenesis as a doubleedged sword as well as investigate the TGase production in UV induced RIF-resistant mutants, besides ISSR-PCR tool to study the genetic diversity between wild type and its mutants. Moreover, TGase was purified from the selected strain in both wild and mutant types, and its biochemical characteristics were investigated.

\section{Materials and Methods}

\subsection{Materials.}

Carbobenzoxy glutamine glycine (CBZ-Gln-Gly), glutathione (reduced form), Lglutamic acid $\gamma$-monohydroxamate, hydroxylamine, and SephadexG-100 were purchased from Sigma-Aldrich Co., Inc., Germany. Trichloroacetic acid (TCA), ferric chloride were purchased from S.D. Fine Chemical Ltd., India. DEAE-Sephadex A-50 was purchased from Fluka BioChemica Buchs, Switzerland. Bovine serum albumin (BSA) was purchased from Mallinckrodf Chemical Co., Inc, France. Dye Coomassie brilliant blue G-250 was purchased from Bio-Rad (Richmond, Calif., USA).All other used reagents and chemicals were of analytical grade. 


\subsection{Methods.}

2.2.1. Bacterial strains and culture conditions.

Three Lab stock molecularly identified bacterial strains, including Bacillus licheniformis ATM14, Cronobacter muytjensii GH10, Bacillus subtilis subsp. subtilis 168, as well as three unidentified bacterial isolates described as NRC215, NRC216, and NRC217 were used to check their ability for TGase production. The bacterial strains were maintained on slants of Luria-Bertani (LB) agar media (Hi-media, Mumbai, India). The slants of bacterial strains were incubated at $37^{\circ} \mathrm{C}$ overnight and then stored at $4{ }^{\circ} \mathrm{C}$ for further studies.

\subsubsection{Screening of TGase producing strains.}

The bacterial strains were cultivated in SPYG medium ( $\mathrm{pH} 7.0$ ) comprising of soluble starch $(20 \mathrm{~g} / \mathrm{L})$, peptone $(2 \mathrm{~g} / \mathrm{L})$, yeast extract $(2 \mathrm{~g} / \mathrm{L})$, magnesium sulfate $(2 \mathrm{~g} / \mathrm{L})$, potassium dihydrogen phosphate $(2 \mathrm{~g} / \mathrm{L})$, and dipotassium phosphate $(2 \mathrm{~g} / \mathrm{L})$ for $60 \mathrm{~h}$ at $37{ }^{\circ} \mathrm{C}, 180 \mathrm{rpm}$ [16]. The ability of different bacterial strains was checked for TGase production in the cell-free supernatant (crude TGase extract) using hydroxamate assay.

\subsubsection{Hydroxamate assay of TGase activity.}

TGase activity was determined using hydroxamate assay according to Folk and Cole (1966) [24]. One unit of TGase activity is calculated as the amount of enzyme required to produce $1 \mu$ mole of hydroxamate per minute at $37^{\circ} \mathrm{C}$ from the reaction of CBZ-Gln-Gly and hydroxylamine using the calibration curve of L-glutamic acid $\gamma$-monohydroxamate. TGase specific activity is calculated by divided TGase activity by the protein content.

\subsubsection{Determination of protein content.}

The protein content of all resulting fractions was determined using Coomassie brilliant blue G-250 dye, according to Bradford (1976) [25]. The developed color was measured at 595 nm, using UV 1201-vis spectrophotometer SHIMDZU, Japan. The calibration curve was prepared using BSA as a standard protein.

2.2.5. Molecular identification of the selected bacterial isolate by PCR amplification and sequencing of $16 \mathrm{~S}$ rDNA.

\subsubsection{Extraction of genomic DNA.}

A single colony of the bacterial isolate was cultured in a conical flask containing $20 \mathrm{ml}$ of an LB medium by shaking in an orbital shaker at $150 \mathrm{rpm}$ for $18 \mathrm{~h}$. The culture was centrifuged at $13,000 \mathrm{rpm}$ for $5 \mathrm{~min}$ at $4^{\circ} \mathrm{C}$. The pellet was subjected to genomic DNA extraction using the (QIAamp DNA Mini Kit, QIAGEN, Germany). The extracted DNA was used as a template for PCR to amplify the $16 \mathrm{~S}$ rDNA gene.

\subsubsection{Amplification and sequencing of $16 S \mathrm{rDNA}$.}

Bacterial 16S rDNA was amplified by PCR using the universal primers; $8 \mathrm{f}$ (5'AGAGTTTGATCCTGGCTCAG3') and 1492R (5'GGTTACCTTGTTACGACTT3'), thereby producing an amplicon of $\sim 1500 \mathrm{bp}$ [26], amplification was carried out in $50 \mu \mathrm{l}$ 
reactions by using PCR Master Mix 2x concentration (Thermo scientific, USA), according to the manufacturer's instructions using a GeneAmp PCR System 2400 Thermal cycler (PerkinElmer Norwalk, Connecticut, USA). The following program was used: $94{ }^{\circ} \mathrm{C}$ for $3 \mathrm{~min}$ as initial denaturation step, followed by 35 cycles of denaturation at $94{ }^{\circ} \mathrm{C}$ for $30 \mathrm{sec}$, annealing at $55^{\circ} \mathrm{C}$ for $30 \mathrm{sec}$, extension at $72{ }^{\circ} \mathrm{C}$ for $2 \mathrm{~min}$, with a final extension at $72{ }^{\circ} \mathrm{C}$ for $10 \mathrm{~min}$. PCR products were purified by QIAquick PCR Purification Kit (Germany) following resolving by electrophoresis on $1 \%$ agarose gels and compared to a $1 \mathrm{~kb}$ DNA ladder (Thermo scientific, USA). Gel purification was accomplished by gel extraction kit QIAquick (Qiagen, Germany). The nucleotide sequence was determined using the same primers with the dideoxy-chain termination method (Clinilab, Egypt). The obtained sequences were analyzed for similarities to other known sequences found in the GenBank database using BLAST program of the NCBI database https://blast.ncbi.nlm.nih.gov/Blast.

\subsubsection{Transglutaminase improvement by UV mutagenesis.}

One milliliter of eighteen-hour-old bacterial culture (saturated culture) was resuspended in $50 \mathrm{ml}$ LB medium-containing flasks for $4 \mathrm{~h}$ to ensure that cells were in exponential phase and that according to Alireza (2016) [27]. For UV treatment, $10 \mathrm{ml}$ of saturated culture were centrifuged, washed twice, and re-suspended in an equal volume of 50 $\mathrm{mM}$ phosphate buffer, $\mathrm{pH} 7.0$, and 2-ml sample was evenly placed in a sterile glass petri dish (5 $\mathrm{cm}$ in diameter). One plate was kept in the dark, which served as control, and the rest were exposed to UV-light (A 30-w germicidal lamp at $254 \mathrm{~nm}$ (VL-130.G, Vilber, Germany) from a distance of $20 \mathrm{~cm}$ for 3, 5, and $7 \mathrm{~min}$. After treatment, samples were immediately diluted at 1:10 in LB medium-containing flasks wrapped in tin foil and grown to saturation. Then, appropriate cell dilutions from treated and control samples were spread on LB plates with and without RIF $(100 \mu \mathrm{g} / \mathrm{ml})$ to isolate induced and spontaneous RIF resistant mutation, respectively. Assessment of TGase production in RIF's resistant mutants and RIF sensitive mutants was done to elucidate if there is a relation between antibiotic fitness and enzyme production in bacterial strain.

\subsubsection{Molecular differentiation of mutants using ISSR amplification.}

Eleven primers, synthesized by Metabion Corporation, Germany, listed in Table 1, amplify DNA with polymorphic and monomorphic bands. ISSR amplifications were performed in $25 \mu \mathrm{l}$ reactions consisting of $2 \mu \mathrm{l}$ of $10 \mu \mathrm{mol}$ primers, $2 \mu \mathrm{l}$ of DNA template, 12.5 $\mu \mathrm{l}$ of PCR Master Mix 2x concentration (Thermo scientific, USA), and 8.5 $\mu$ lof ddH2O. According to Williams et al. (1990) [28], with some modification, PCR condition was done as follow: initial denaturation at $95^{\circ} \mathrm{C}$ for $3 \mathrm{~min}$, followed by 35 cycles of $30 \mathrm{~s}$ at $94{ }^{\circ} \mathrm{C}, 30 \mathrm{~s}$ at $45^{\circ} \mathrm{C}, 2 \mathrm{~min}$ at $72{ }^{\circ} \mathrm{C}$, and final extension of $15 \mathrm{~min}$ at $72{ }^{\circ} \mathrm{C}$ using a GeneAmp PCR System 2400 Thermal cycler (Perkin-Elmer Norwalk, Connecticut, USA).

\subsubsection{Detection of the PCR products.}

The amplification products were resolved by electrophoresis in a $1.5 \%$ agarose gel containing ethidium bromide $(0.5 \mu \mathrm{g} / \mathrm{ml})$ in $1 \mathrm{X}$ TBE buffer at 95 volts. PCR products were visualized on UV light and photographed using a Gel Documentation System (BIO-RAD 2000). 


\subsubsection{Data analysis.}

The banding patterns generated by ISSR marker analyses were compared to determine the genetic relatedness of the samples under study. Clear and distinct amplification products were scored as ' 1 ' for presence and ' 0 ' for the absence of bands. Bands of the same mobility were scored as identical. The genetic similarity coefficient (GS) between two genotypes was estimated according to Dice coefficient [29], Dice formula: GSij $=2 a /(2 a+b+c)$

Where GSij is the measure of genetic similarity between individuals $i$ and $j$, $a$ is the number of bands shared by $i$ and $j, b$ is the number of bands present in $i$ and absent in $j$, and $c$ is the number of bands present in $\mathrm{j}$ and absent in $\mathrm{i}$.

The similarity matrix was used in the cluster analysis. The cluster analysis was employed to organize the observed data into meaningful structures to develop taxonomies. At the first step, when each accession represents its cluster, the distances between these accessions are defined by the chosen distance measure (Dice coefficient). However, once several accessions have been linked together, the distance between two clusters is calculated as the average distance between all pairs of accessions in the two different clusters. This method is called Unweighted Pair Group Method using Arithmetic Average (UPGMA) [29].

Table 1. Nucleotide sequence of ISSR primers.

\begin{tabular}{l|l} 
Primer Name & Sequence \\
\hline ISSR-1 & 5'-AGAGAGAGAGAGAGAGYC-3' \\
\hline ISSR-2 & 5'-AGAGAGAGAGAGAGAGYG-3' \\
\hline ISSR-3 & 5'-ACACACACACACACACYT-3' \\
\hline ISSR -4 & 5'-ACACACACACACACACYG-3' \\
\hline ISSR -5 & 5'-GTGTGTGTGTGTGTGTYG-3' \\
\hline ISSR -13 & 5'-TCTCTCTCTCTCTCTCA-3' \\
\hline R-1 & 5'-CACACACACACACACARG-3' \\
\hline R-3 & 5'-AGAGAGAGAGAGYC-3' \\
\hline R-6 & 5'-TATATATATATATATAC-3' \\
\hline R-7 & 5'-CTCTCTCTCTCTCTCTT-3' \\
\hline R-9 & 5'-ACACACACACACACACG-3'
\end{tabular}

\subsubsection{Purification of bacterial TGase.}

TGase was purified from the selected bacterial isolate in both wild- and RIF's mutant strains as follow:

\subsubsection{Ammonium sulfate precipitation (ASP).}

TGase was precipitated from the crude TGase extract of the selected bacterial isolate using $\left(\mathrm{NH}_{4}\right)_{2} \mathrm{SO}_{4}$ up to $90 \%$ saturation as described by Colowick and Kaplan (1955) [30]. The sedimentary protein was collected by centrifugation $(5000 \mathrm{rpm}$ for $15 \mathrm{~min})$ at $4{ }^{\circ} \mathrm{C}$. The supernatant is discarded while the precipitate is re-dissolved in $20 \mathrm{mM}$ Tris- $\mathrm{HCl}$ buffer $\mathrm{pH}$ 7.4. TGase activity and protein content of the resulting fractions were determined.

\subsubsection{Ion exchange chromatography (IEX) on DEAE-SephadexA-50.}

The highly active TGase fraction was dialyzed against $20 \mathrm{mM}$ Tris- $\mathrm{HCl}$ buffer $\mathrm{pH} 7.4$ for $24 \mathrm{~h}$ and then applied onto DEAE-Sephadex A-50 column $(1.5 \times 25 \mathrm{~cm})$ equilibrated with $20 \mathrm{mM}$ Tris- $\mathrm{HCl}$ buffer $\mathrm{pH}$ (7.4). The protein fraction is eluted with $\mathrm{NaCl}$ linear gradient at the level of $0-0.5 \mathrm{M}$ in the flow rate of $1.0 \mathrm{ml} / \mathrm{min}$. Fractions were collected, protein absorbance at 
$280 \mathrm{~nm}$ was recorded, and the TGase activity was assayed. Fractions with high TGase activity were pooled and dialyzed for $24 \mathrm{~h}$ against $20 \mathrm{mM}$ Tris- $\mathrm{HCl}$ buffer $\mathrm{pH} 7.4$.

\subsubsection{Size exclusion column chromatography (SEC) on Sephadex G-100.}

The IEX dialyzed fractions of the selected bacterial isolate were further purified by applied on Sephadex G-100 column $(2.5 \times 37 \mathrm{~cm})$ (Pharmacia, Uppsala, Sweden), which equilibrated with $20 \mathrm{mM}$ Tris-HCl buffer $\mathrm{pH}$ (7.4), and the sample was eluted with the same buffer at a flow rate of $1.0 \mathrm{ml} / \mathrm{min}$. The recovered fractions were assayed for TGase activity, and the protein was detected at $280 \mathrm{~nm}$. The rich TGase fractions were pooled and served as purified TGase enzymes.

\subsubsection{TGase biochemical characteristics.}

The biochemical characteristics of the purified TGase the wild-type and its mutant are investigated as follow:

\subsubsection{Optimum $\mathrm{pH}$.}

The TGase enzyme activity was measured at different $\mathrm{pH}$ values ranging from 4-8 using 0.2 M Acetate buffer ( $\mathrm{pH} 4-5$ ), $0.2 \mathrm{M}$ phosphate buffer ( $\mathrm{pH}$ 6-7), and $0.2 \mathrm{M}$ Tris-HCl buffer (pH 8-9). The activity was measured after an incubation period of $10 \mathrm{~min}$ at each $\mathrm{pH}$.

\subsubsection{Optimum temperature.}

The reaction mixture and enzyme extract were incubated at different temperatures ranging from 30 to $70{ }^{\circ} \mathrm{C}$ for $10 \mathrm{~min}$. The enzyme activity was then assayed at each temperature to define the TGase optimal temperature.

\subsubsection{Metal ion susceptibility of TGase.}

The presence of $10 \mathrm{mM}$ of $\mathrm{FeCl}_{3} \cdot 6 \mathrm{H}_{2} \mathrm{O}, \mathrm{MnSo}_{4} \cdot \mathrm{H}_{2} \mathrm{O}, \mathrm{ZnSo}_{4} .7 \mathrm{H}_{2} \mathrm{O}, \mathrm{CuSo}_{4} .5 \mathrm{H}_{2} \mathrm{O}$, MgSo $4.7 \mathrm{H}_{2} \mathrm{O}, \mathrm{BaCl}_{2} .2 \mathrm{H}_{2} \mathrm{O}, \mathrm{NaCl}, \mathrm{CaCl}_{2}$ effect on the purified TGase activity was studied. The residual TGase activity was measured under standard assay conditions after incubation with various reagents, while the sample without any addition served as control $(100 \%)$.

\subsubsection{Statistical analysis.}

All statistical analysis of results was performed by SAS statistical software [31] using the ANOVA procedure to analyze variance. The results were expressed as mean \pm standard error, and the differences between means were tested for significance using Duncan's multiple ranges at $p \leq 0.05$.

\section{Results and Discussion}

\subsection{Hydroxamate assay of TGase producing bacterial strains.}

All six bacterial cultures were screened for TGase production. All tested cultures were accounted as positive TGase producers while NRC215 isolates exhibited the maximum enzyme activity $(0.110 \mathrm{U} / \mathrm{ml})$ with a specific activity of $4.23 \mathrm{U}$ per $\mathrm{mg}$ protein, cultivated in SPYG 
medium ( $\mathrm{pH}$ 7.0) at $37{ }^{\circ} \mathrm{C}$ Table 2. Thus for further studies, NRC215 bacterial isolate was selected for molecular identification.

Table 2. TGase activity in different bacterial strains.

\begin{tabular}{l|c|c} 
Strain & $\begin{array}{c}\text { TGase activity } \\
(\mathbf{U} / \mathbf{m l})\end{array}$ & $\begin{array}{c}\text { Specific activity } \\
(\mathbf{U} / \mathbf{m g})\end{array}$ \\
\hline Bacillus licheniformis & $0.020 \pm 0.003^{\mathrm{cd}}$ & $0.32 \pm 0.035^{\mathrm{d}}$ \\
\hline Cronobacter muytjensii & $0.052 \pm 0.006^{\mathrm{b}}$ & $3.25 \pm 0.029^{\mathrm{b}}$ \\
\hline Bacillus subtilis & $0.046 \pm 0.011^{\mathrm{b}}$ & $2.30 \pm 0.115^{\mathrm{c}}$ \\
\hline NRC215 & $0.110 \pm 0.005^{\mathrm{a}}$ & $4.23 \pm 0.052^{\mathrm{a}}$ \\
\hline NRC216 & $0.036 \pm 0.006^{\mathrm{bc}}$ & $2.40 \pm 0.115^{\mathrm{c}}$ \\
\hline NRC217 & $0.014 \pm 0.0009^{\mathrm{d}}$ & $0.21 \pm 0.052^{\mathrm{d}}$
\end{tabular}

\subsection{Molecular identification of the selected bacterial isolate by $16 \mathrm{~S}$ rDNA sequencing.}

The highest TGase producer bacterial isolate was selected based on quantitative hydroxamate assay of TGase production was identified through $16 \mathrm{~S}$ rDNA sequencing. The universal primers of the 16s rDNA gene amplified $\sim 1500 \mathrm{bp}$ in the selected bacterial isolate NRC215 (Figure 1). 16S rDNA sequence was subjected to BLAST search on https://blast.ncbi.nlm.nih.gov/Blast against the available sequences deposited in the NCBI database. 16S rDNA gene sequence of the bacterial isolate scored $99.5 \%$ identity with Bacillus cereus strain 2.3AL8. Hence, the highest bacterial isolate producer for TGase was recorded as Bacillus cereus NRC215 under accession number MT229271 in the NCBI database.

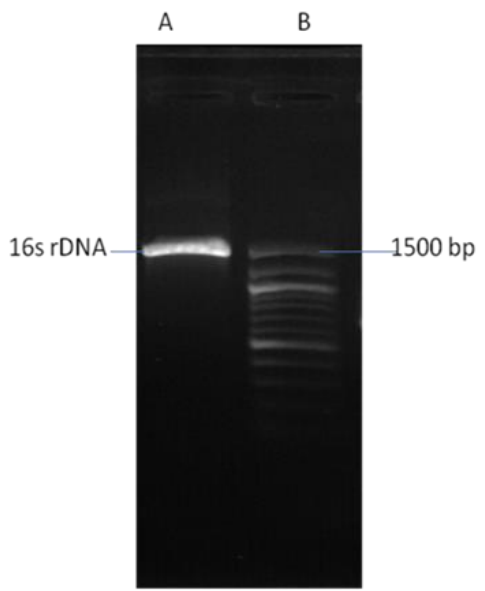

Figure 1. Agarose gel electrophoresis for PCR product of 16s rDNA in NRC215 bacterial isolate (A), and 100bp DNA ladder (B).

\subsection{Screening of $U V$-induced rifampin-resistant mutants.}

Five RIF resistant mutants were only isolated from UV-treated Bacillus cereus NRC215 for three minutes; however, no RIF resistant mutants were isolated from UV treatment for five and seven minutes. Simultaneously, no RIF resistant mutants were isolated from control and that after spreading a suitable aliquot on LB agar containing RIF (spontaneous resistance). The frequency of RIF's mutants can be interpreted by a higher content of ribosomal genes and paradigm. Vogler (2002) [32] isolated 20 and 23 RIF-resistant mutants from UV-light-treated Bacillus cereus and attenuated $B$. anthracis, respectively. Spontaneous UV RIF resistant mutants were reported only in B. anthracis; they concluded that the difference in UV mutation profiles of RIF resistance that occur in these two species may be due to the difference in repair mechanisms used by them. The mechanisms behind RIF's resistance in B. anthracis and $B$. cereus are similar to mechanisms found in other species. Besides, other unique mutations 
confer RIF's resistance in both of these species. A common mechanism is utilized by bacterial strains such as E. coli and Bacillus after DNA damage by UV treatment. This mechanism is directed to repair this damage and mostly resulted in amino acids substitution in the beta subunit of RNA polymerase, encoded by the rpoB gene; thus, it alters the RIF binding pocket and prevents RIF from binding to its specific pocket [33]. It could be assumed that the high content of A+T (65\%) of the total genome in Bacillus cereus increases the likelihood of UVinduced thymine dimer formation, which subsequently may cause the appearance of RIF's resistant mutants. UV treatment for different times decreased the survival rate by increasing the exposure time to UV light. For three, five, and seven minutes UV treatment, survival rates were $35 \%, 13 \%$, and $5 \%$, respectively.

\subsection{Hydroxamate assay of TGase in the bacterial mutants.}

The introduction of mutations conferring resistance to a drug that attacks the ribosome is considered a conventional method to modulate the ribosome. Mutants that have resistance to drugs such as rifampicin, streptomycin, gentamicin, paromomycin, thiostrepton, fusidic acid, kanamycin, chloramphenicol, lincomycin, spectinomycin, and neomycin, frequently possess mutations in a ribosomal component (rRNA, ribosomal protein, or translation factor), so that it gives an advantage of the selection of drug-resistant mutants on a drug containing plates [34]. From this point, RIF-resistant mutants of Bacillus cereus NRC215 were isolated and tested for TGase production compared with wild type. All single colonies of bacterial mutants grown on LB agar plates containing and lacking the antibiotic were selected and tested for the production of TGase. The highest TGase activity was recorded by BCrif5 $(0.148 \mathrm{U} / \mathrm{ml})$ compared with wild type $(0.101 \mathrm{U} / \mathrm{ml})$, as shown in Table 3 . It means that UV mutagenesis of Bacillus cereus NRC215 (BCrif5) increases TGase production and its activity by $\sim 0.5$ fold compared to wild strain, which reflects increasing of BCrif5 specific activity ( $6.43 \mathrm{U} \mathrm{mg}^{-1}$ protein) compared to wild strain type of $4.23 \mathrm{U} \mathrm{mg}^{-1}$ protein as shown in Table 3. This mutant was selected from LB agar plates with rifampin $100 \mu \mathrm{g} / \mathrm{ml}$. The increase in activity of TGase enzyme can be explained as follow; UV mutation conferring Rif resistance fitness to BCrif5 mostly resulted in point mutation in rpoB gene, which subsequently encodes mutant $\beta$-subunit of RNA polymerase with higher affinity to the promotor of tgl gene and caused higher activity. Other explanations can be considered, such as the occurrence of the point mutation in the structure gene, tgl, which is expected to be raised due to UV irradiation, can change specific amino acids sequences which may subsequently confer higher affinity between the encoding enzyme and its specific substrate especially the optimum $\mathrm{pH}$ of this modified enzyme, transglutaminase, varied from that of enzyme in the wild strain as will mentioned in the rest parts. Since transglutaminase is a secondary metabolite, usually commences during the late growth phase, it would be expected that with enhanced protein synthesis, thus the production of TGase as an extracellular enzyme will be increased. Funane et al. (2018) [35] stated that spontaneous rifampicin-resistant mutants in Paenibacillus agaridevorans recorded a higher yield of amylase, proteases, and agarase than its wild strain. Hence, the simplicity and wide applicability of this method should be facilitated for both productions of TGase on an industrial scale and the identification of dormant enzymes by activating the expression of silent or weakly expressed genes.

Other literature elucidates the efficiency of RIF resistant mutants in the production of other industrial enzymes such as protease in Bacillus subtilis [36]. Tanaka et al. (2013) [37] concluded increasing the affinities of mutant RNA with certain rifampin-resistant (Rifr) rpoB 
mutations in polymerases for promoters of certain genes in S. coelicolor, and that eventually enhanced the transcription of antibiotic biosynthesis genes and activated antibiotic production. Also, Perkins and Nicholson (2018) [38] announced that rifampicin-resistant mutants of $B$. subtilis enabled them to use novel substrates previously unknown in this organism, such as gentiobiose and D-psicose. Tanaka et al. (2013) [37] introduced certain RIF resistant mutants of Streptomyces griseus that effectively exhibited increased streptomycin antibiotic production, while RIF-resistant mutations alter RNA polymerase function, comparison of transcription patterns within genes involved in TGase production in wild type versus rifampicin-resistant mutants is the ideal next step to identify novel genes whose transcription are up-or downregulated in particular RIF resistant mutants, for further molecular and metabolic analysis.

Table 3. TGase activity of Bacillus cereus NRC215 RIF resistant mutants.

\begin{tabular}{l|c|c} 
Strain/RIF mutants & $\begin{array}{c}\text { TGase activity } \\
(\mathbf{U} / \mathbf{m l})\end{array}$ & $\begin{array}{c}\text { Specific activity } \\
(\mathbf{U} / \mathbf{m g})\end{array}$ \\
\hline B. cereus NRC215 (wild) & $0.110 \pm 0.006^{\mathrm{cd}}$ & $4.23 \pm 0.017^{\mathrm{e}}$ \\
\hline BCrif1 & $0.104 \pm 0.005^{\mathrm{cd}}$ & $5.20 \pm 0.029^{\mathrm{d}}$ \\
\hline BCrif2 & $0.124 \pm 0.003^{\mathrm{b}}$ & $5.90 \pm 0.069^{\mathrm{c}}$ \\
\hline BCrif3 & $0.101 \pm 0.003^{\mathrm{d}}$ & $5.94 \pm 0.066^{\mathrm{bc}}$ \\
\hline BCrif4 & $0.115 \pm 0.0009^{\mathrm{bc}}$ & $6.05 \pm 0.029^{\mathrm{b}}$ \\
\hline BCrif5 & $0.148 \pm 0.0009^{\mathrm{a}}$ & $6.43 \pm 0.038^{\mathrm{a}}$
\end{tabular}

\subsection{Molecular differentiation using ISSR technique.}

The ISSR PCR technique was used to detect the genetic variability between Bacillus cereus NRC215 as a wild type (No. 1) and its RIF resistant mutants (No. 2-6). In this study, all eleven ISSR primers produced scorable and reproducible banding patterns (representative of these PCR products are shown in Figure 2). A total of 175 full bands were scored from the amplified products and ranged between 7 (in ISSR-2) and 22 (in ISSR-7). All primers gave monomorphic bands except one primer ISSR-4. Polymorphic bands are informative in identification through two ways, the first is the releasing of unique banding patterns to individual species, and the second is in the presence or absence of unique band(s) (marker bands) that distinguish an individual from its population. As a primer's discriminatory power is related to its amplified polymorphic bands relative to that produced by the rest of all primers, it is essential to determine its DNA fingerprint. Primer ISSR-7 reflected high discriminatory power as compared with other primers. The maximum number of unique bands was amplified by primer ISSR-9, which recorded 4 bands, whereas ISSR-2 did not amplify any unique bands. These results showed that ISSR primers are robust and informative and would be a better tool for genetic diversity and phylogenetic studies. Primers of ISS-7 and ISSR-9 were considered the best primers in differentiation between wild and mutant types, as with high numbers of nonunique and unique polymorphic bands, as shown in Table 4. These variations in ISSR banding patterns might be connected with structural rearrangements in DNA caused by different types of DNA damages caused by UV mutagenesis. As shown in Table 5 and Figure 3, a phylogenetic tree illustrated two distinct groups. The first group) included one cluster with one strain, BCrif3 (No. 4), with a low genetic similarity ratio $68 \%$ with wild-type strain (No. 1). On the other hand, the second group included wild type strain and their mutants of BCrif1 (No.2), BCrif2 (No.3), BCrif4 (No.5), and BCrif5 (No.6) with different distances between them in two poolclusters [BCrif2 (No.3) and BCrif4 (No.5)]. It's had one sub-group close distance between them of 77\%, while sup-group B includes BCrif1 (No.2) and BCrif5 (No.6) with a distance of 76\%. In another study conducted by Akramipour et al. (2017) [39], the ISSR molecular markers were used to evaluate the genetic diversity assessment in microbial diversity. Also, Verma et 
al. (2018) [40] used seven ISSR to study the genetic diversity of three different Bacillus isolates used to enhance sustainable agricultural productivity, as they promote a consortium in the drought-tolerant plant.

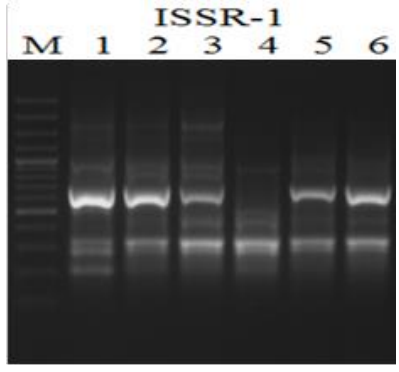

ISSR-4
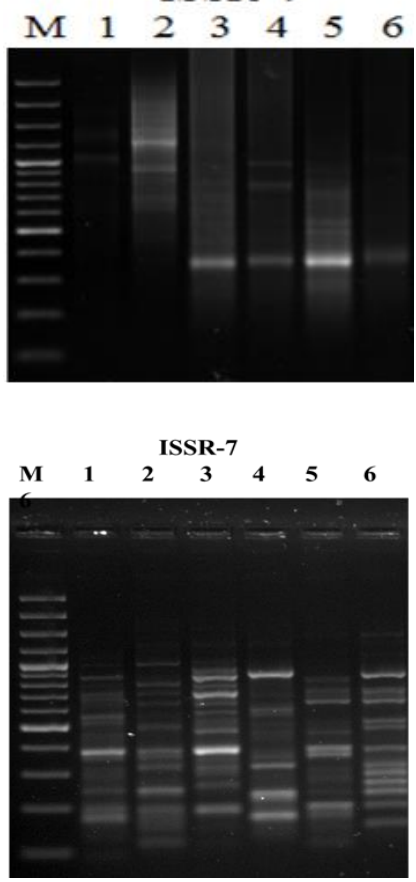

ISSR-10

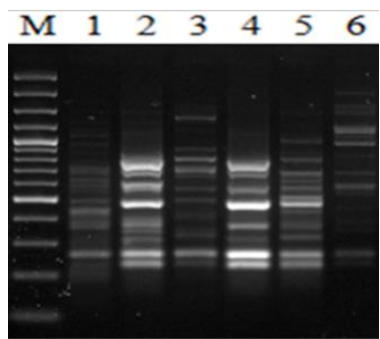

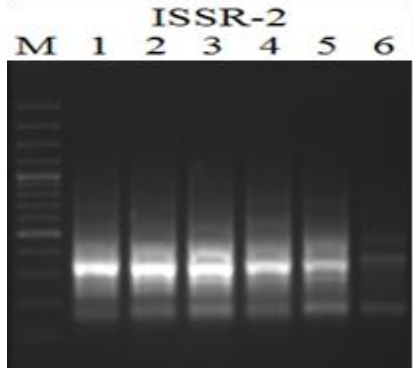

ISSR-5

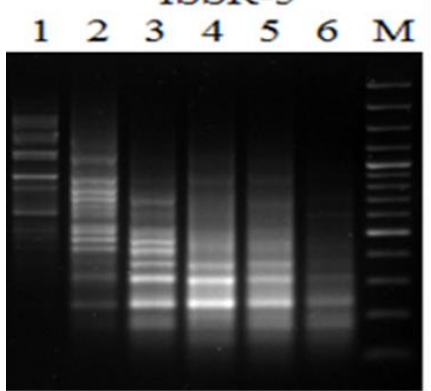

ISSR-8

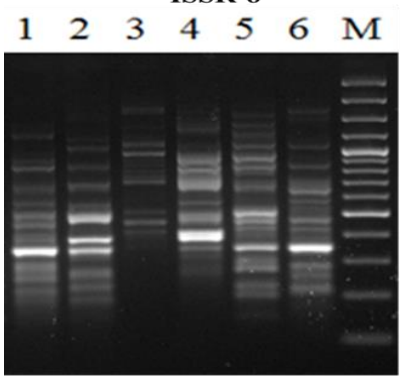

ISSR-11

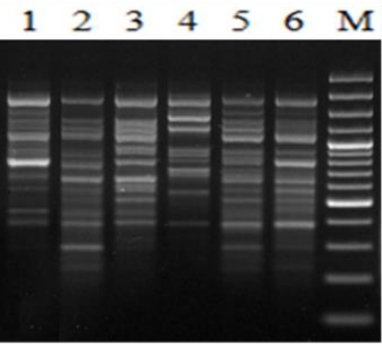

ISSR-3

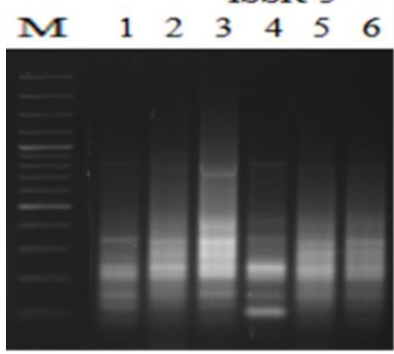

ISSR-6

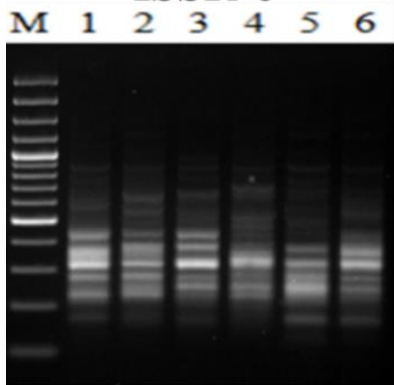

ISSR-9

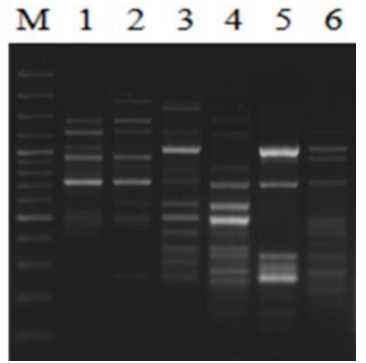

Figure 2. Agarose gel electrophoresis for PCR products of ISSR primers in BCNRC215 (1), and rifampicinresistant mutants (2-6) .M 100bp DNA ladder enzynomics.

Table 4. Fragments amplified by the eleven ISSR primers in Bacillus cereus NRC215 and its rifampin mutants and mean frequency of each primer.

\begin{tabular}{|c|c|c|c|c|c|c|c|}
\hline \multirow{2}{*}{ Primers } & \multirow{2}{*}{$\begin{array}{l}\text { Monomorphi } \\
\text { c bands* }\end{array}$} & \multicolumn{2}{|c|}{$\begin{array}{l}\text { polymorphic } \\
\text { bands } * *\end{array}$} & \multirow{2}{*}{$\begin{array}{l}\text { Total } \\
\text { bands }\end{array}$} & \multirow{2}{*}{$\begin{array}{c}\text { Polymorphism }(\%) \\
=\begin{array}{c}\text { polymorphic bands } \\
\text { /total bands }) * 100\end{array}\end{array}$} & \multirow{2}{*}{$\begin{array}{l}\text { MW } \\
\text { (bp) }\end{array}$} & \multirow{2}{*}{$\begin{array}{c}\text { Mean of } \\
\text { frequency }\end{array}$} \\
\hline & & $\begin{array}{c}\text { Non- unique } \\
\text { bands }\end{array}$ & $\begin{array}{l}\text { unique } \\
\text { bands }\end{array}$ & & & & \\
\hline ISSR-1 & 5 & 8 & 1 & 14 & 64 & $200-1600$ & 0.7 \\
\hline ISSR-2 & 4 & 3 & 0 & 7 & 43 & $180-720$ & 0.9 \\
\hline ISSR-3 & 8 & 2 & 1 & 11 & 27 & $140-890$ & 0.8 \\
\hline ISSR-4 & 0 & 11 & 2 & 13 & 100 & $260-1350$ & 0.4 \\
\hline ISSR-5 & 4 & 13 & 1 & 18 & 78 & $160-1500$ & 0.6 \\
\hline ISSR-6 & 5 & 9 & 1 & 15 & 67 & $170-1250$ & 0.7 \\
\hline ISSR-7 & 3 & 17 & 2 & 22 & 86 & $114-1400$ & 0.6 \\
\hline
\end{tabular}




\begin{tabular}{|c|c|c|c|c|c|c|c|}
\hline \multirow{2}{*}{ Primers } & \multirow{2}{*}{$\begin{array}{l}\text { Monomorphi } \\
\text { c bands* }\end{array}$} & \multicolumn{2}{|c|}{$\begin{array}{l}\text { polymorphic } \\
\text { bands** }\end{array}$} & \multirow{2}{*}{$\begin{array}{r}\text { Total } \\
\text { bands }\end{array}$} & \multirow{2}{*}{$\begin{aligned} & \text { Polymorphism }(\%) \\
= & (\text { polymorphic bands } \\
& / \text { total bands }) * 100\end{aligned}$} & \multirow{2}{*}{$\begin{array}{l}\text { MW } \\
\text { (bp) }\end{array}$} & \multirow{2}{*}{$\begin{array}{c}\text { Mean of } \\
\text { frequency }\end{array}$} \\
\hline & & $\begin{array}{c}\text { Non- unique } \\
\text { bands }\end{array}$ & $\begin{array}{l}\text { unique } \\
\text { bands }\end{array}$ & & & & \\
\hline ISSR-8 & 4 & 13 & 2 & 19 & 79 & $160-1500$ & 0.6 \\
\hline ISSR-9 & 3 & 12 & 4 & 19 & 84 & $180-1700$ & 0.5 \\
\hline ISSR-10 & 6 & 11 & 3 & 20 & 70 & $210-1800$ & 0.6 \\
\hline ISSR-11 & 8 & 9 & 0 & 17 & 53 & $210-2000$ & 0.8 \\
\hline Total & 50 & 108 & 17 & 175 & & & \\
\hline
\end{tabular}

Table 5. The similarity matrix between Bacillus cereus NRC215wild type and its mutants.

\begin{tabular}{l|c|c|c|c|c|c} 
& Wild type & M1 & M2 & M3 & M4 & M5 \\
\hline Wild & 100 & & & & & \\
\hline M1 & 71 & 100 & & & & \\
\hline M2 & 68 & 76 & 100 & & & \\
\hline M3 & 68 & 69 & 70 & 100 & & \\
\hline M4 & 70 & 74 & 77 & 69 & 100 & \\
\hline M5 & 72 & 76 & 76 & 68 & 76 & 100
\end{tabular}

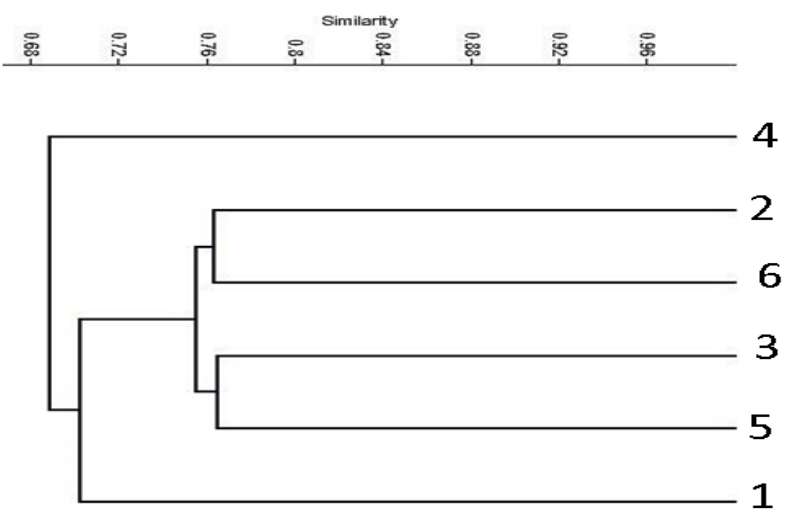

Figure 3. The genetic dendrogram illustrated genetic fingerprint and relationships between Bacillus cereus NRC215 (1) and its rifampin-resistant mutants (2-6) revealed by their ISSR markers.

\subsection{Purification of TGase.}

TGase was extracted and purified from Bacillus cereus NRC215 in both wild and mutant (BCrif5) types using successive purification procedures: salting with ammonium sulfate (ASP), IEX on DEAE-Sephadex A-50, and SEC on Sephadex G-100.

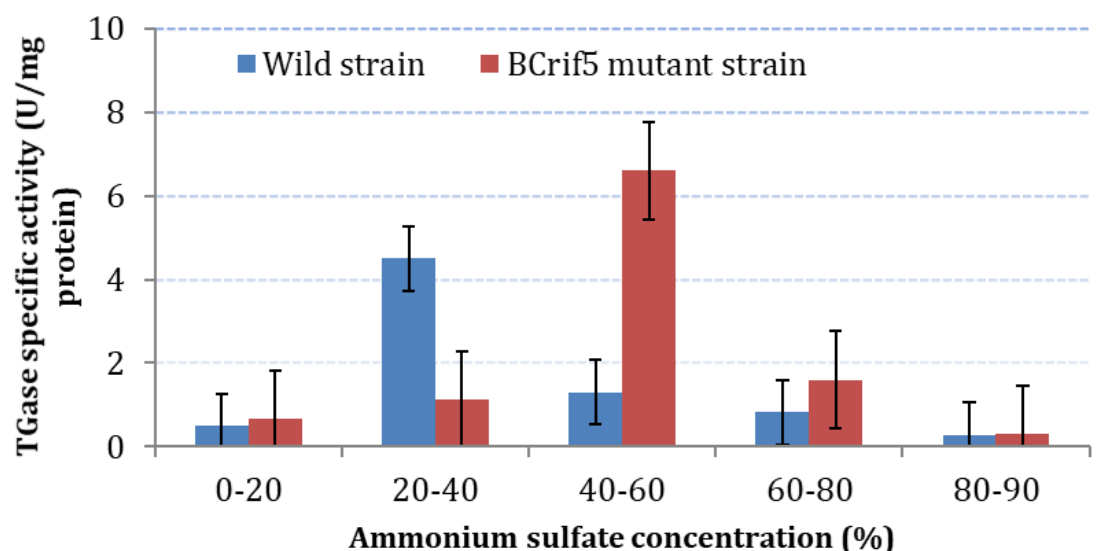

Figure 4. ASP of TGase specific activity from Bacillus cereus NRC215 in both wild and BCrif5 mutant types.

ASP procedure was used to purify of TGase from Bacillus cereus NRC215 partially. It was observed that $20-40 \%$ saturation of ammonium sulfate in wild type exhibited the highest TGase activity $\left(0.090 \mathrm{U} \mathrm{ml}^{-1}\right)$ with a specific activity of $4.50 \mathrm{U} \mathrm{mg}^{-1}$ protein, as presented in Figure 4. Also, TGase was precipitated from the BCrif5 with 40-60\% with the activity of 0.132 
$\mathrm{U} \mathrm{ml}^{-1}$ and $6.60 \mathrm{U} \mathrm{mg}^{-1}$ protein as a specific activity. However, ammonium sulfate saturation and UV mutagenesis of Bacillus cereus NRC215 improved the TGase production, and its activity was increased with higher specific activity than the wild strain type.

The dialyzed rich TGase of ASP fractions from Bacillus cereus NRC215 were applied to DEAE-Sephadex A-50 column for TGase purification by IEX technique with $\mathrm{NaCl}$ lineargradient (0.0-0.5 M). Fig. 5A, showed that one peak of TGase eluted at $0.2 \mathrm{M} \mathrm{NaCl}$ for the wild Bacillus cereus NRC215 and its mutant type (Figure 5B). The DEAE-Sephadex A-50 elution profile of TGase from Bacillus cereus NRC215 was similar to other TGases such as epidermal TGase was eluted at $0.2 \mathrm{M} \mathrm{NaCl}$ [41], and rat brain TGase was eluted with $\mathrm{NaCl}$ at the level of $0.35 \mathrm{M}$ [42]. However, TGase recovery of the wild Bacillus cereus NRC215strainwas $36.91 \%$ with a purification fold of 1.28 Table 6; while TGase was purified 1.12-fold from the mutant culture (BCrif5) with $43.58 \%$ recovery with $7.17 \mathrm{U} \mathrm{mg}^{-1}$ protein as a specific activity Table 7 . The higher TGase recovery of mutant type strain compared to the wild type mainly due to the higher activity and UV mutagenesis improvement of TGase production in Bacillus cereus NRC215 strain. TGase recovery is similar to Gerber et al. (1994) [43] and Cui et al. (2007) [44], who reported that IEX of TGase purification from Streptoverticillium mobaraense, Streptomyces hygroscopicus recorded 50, 57\% as recovery, respectively.

Further purification of TGase was performed using SEC on the Sephadex G-100 column. The results showed that TGase was eluted effectively as a single peak from the wild Bacillus cereus NRC215 with the highest activity in fraction No. 8 as shown in Figure 6A, while two peaks were recorded from BCrif5with the highest activity in fraction No. 7 (Figure 6B). Kobayashi et al. (1998) [45] purified TGase from Bacillus subtilis by gel filtration with one peak. Also, Table 6 showed that the TGase from wild Bacillus cereus NRC215 was purified 1.82-fold from the culture cleared supernatant with $28 \%$ recovery and specific activity of 7.70 $\mathrm{U} \mathrm{mg}{ }^{-1}$ protein, while TGase of the mutant strain was purified 1.28-fold from the culture cleared supernatant with $36.63 \%$ recovery with $8.20 \mathrm{U} \mathrm{mg}^{-1}$ protein as a specific activity Table 7. This recovery is similar to that obtained from previously described laboratory-scale procedures, ranging from $20 \%$ to $63 \%$ depending on the procedure used [13,14,46,].

\subsection{Biochemical characterization of TGase.}

\subsubsection{Effect of $\mathrm{pH}$ on TGase activity.}

TGase enzyme activity of the selected Bacillus cereus NRC215for both wild and mutant (BCrif5) types at different $\mathrm{pH}$ values ranging from 4-8 was described in Figure 7. It was observed that the optimal $\mathrm{pH}$ of TGase from wild strain was found to be 7.0, while the mutant BCrif5 exhibits their maximum TGase activity at $\mathrm{pH}$ 5.0, it was declined sharply at alkaline $\mathrm{pH}$, while it gradually increased at the acidic $\mathrm{pH}$ condition. It could be due to the influence of reaction mixture $\mathrm{pH}$, which affects the conformation and configuration of the active site and catalytic site of the TGase enzyme, as well as the net charge of protein [46]. The optimal pH of TGase from wild Bacillus cereus NRC215 was similar to microbial TGase from Streptoverticillium sp. [43,44], Bacillus circulans [48]; as well as plant TGase extracted from soybean (Glycine max L.) [49], pea (Pisum sativum), bean (Vicia faba), wheat (Triticuma estivum), barley (Hordeum vulgare) [11], rosemary (Rosmarinus officinalis L.) [12]. Also, the optimal pH (5.0) of TGase from mutant Bacillus cereus NRC215 as well as their higher activity in acidic conditions compared to TGase activity from wild strain may prove to be a good 
candidate as a food additive for dairy products that could be easily controlled in the industrial application as designed.
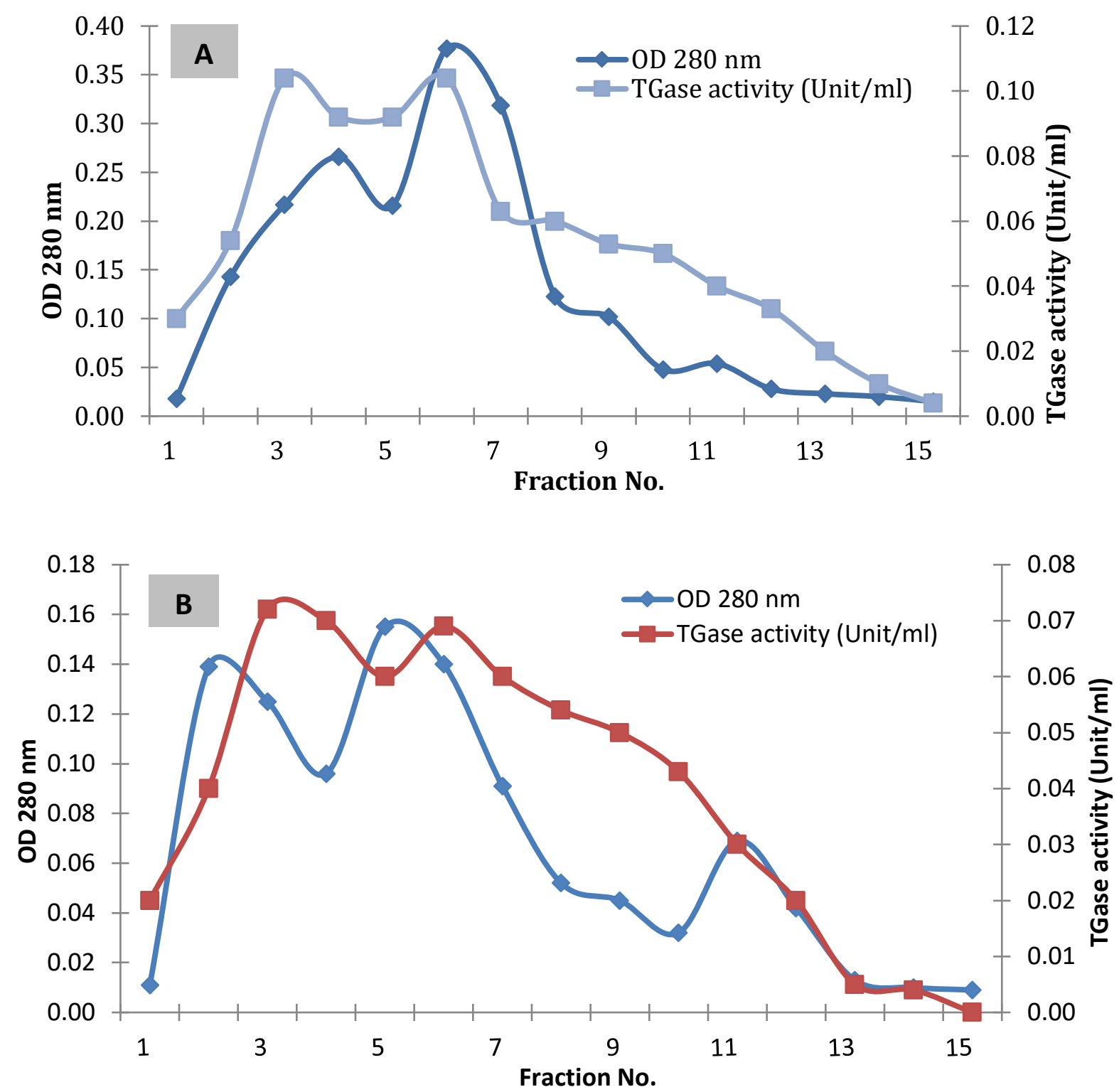

Figure 5. Ion exchange chromatography on DEAE-SephadexA-50 of TGase from Bacillus cereus NRC215 and BCrif5. (A, wild strain; B, mutant strain).

Table 6. Purification of TGase from wild type of Bacillus cereus NRC215.

\begin{tabular}{l|c|c|c|c|c}
$\begin{array}{c}\text { Purification } \\
\text { step }\end{array}$ & $\begin{array}{c}\text { Total TGase activity } \\
(\mathbf{U})\end{array}$ & $\begin{array}{c}\text { Total protein } \\
(\mathbf{m g})\end{array}$ & $\begin{array}{c}\text { Specific activity } \\
\text { (U/mg protein) }\end{array}$ & $\begin{array}{c}\text { Recovery } \\
(\boldsymbol{\%})\end{array}$ & $\begin{array}{c}\text { Purification } \\
\text { fold }\end{array}$ \\
\hline Crude extract & 5.50 & 1.3 & 4.23 & 100 & 1.00 \\
\hline ASP & 2.70 & 0.60 & 4.50 & 49.09 & 1.06 \\
\hline IEX & 2.03 & 0.38 & 5.40 & 36.91 & 1.28 \\
\hline SEC & 1.54 & 0.20 & 7.70 & 28.00 & 1.82
\end{tabular}

Recovery $=$ Total activity of purified enzyme/Total activity of crude enzyme X 100; Purification fold= Specific activity of purified enzyme/Specific activity of crude enzyme; ASP, Ammonium sulfate precipitation; IEX, Ion exchange chromatography; SEC, Size exclusion column chromatography.

3.7.2. Effect of temperature on TGase activity.

TGase from the selected wild Bacillus cereus NRC215 and mutant (BCrif5) exhibits their optimal activity at $40^{\circ} \mathrm{C}$, as shown in Figure 8 . This finding was similar to microbial TGase from Streptomyces hygroscopicus [44], Bacillus circulans [50], and soybean (Glycine max L.) 
TGase [49]. The temperature of the reaction mixture influences the conformation and configuration of the active site and catalytic site of TGase enzyme, which affects its protein structure during the incubation time.
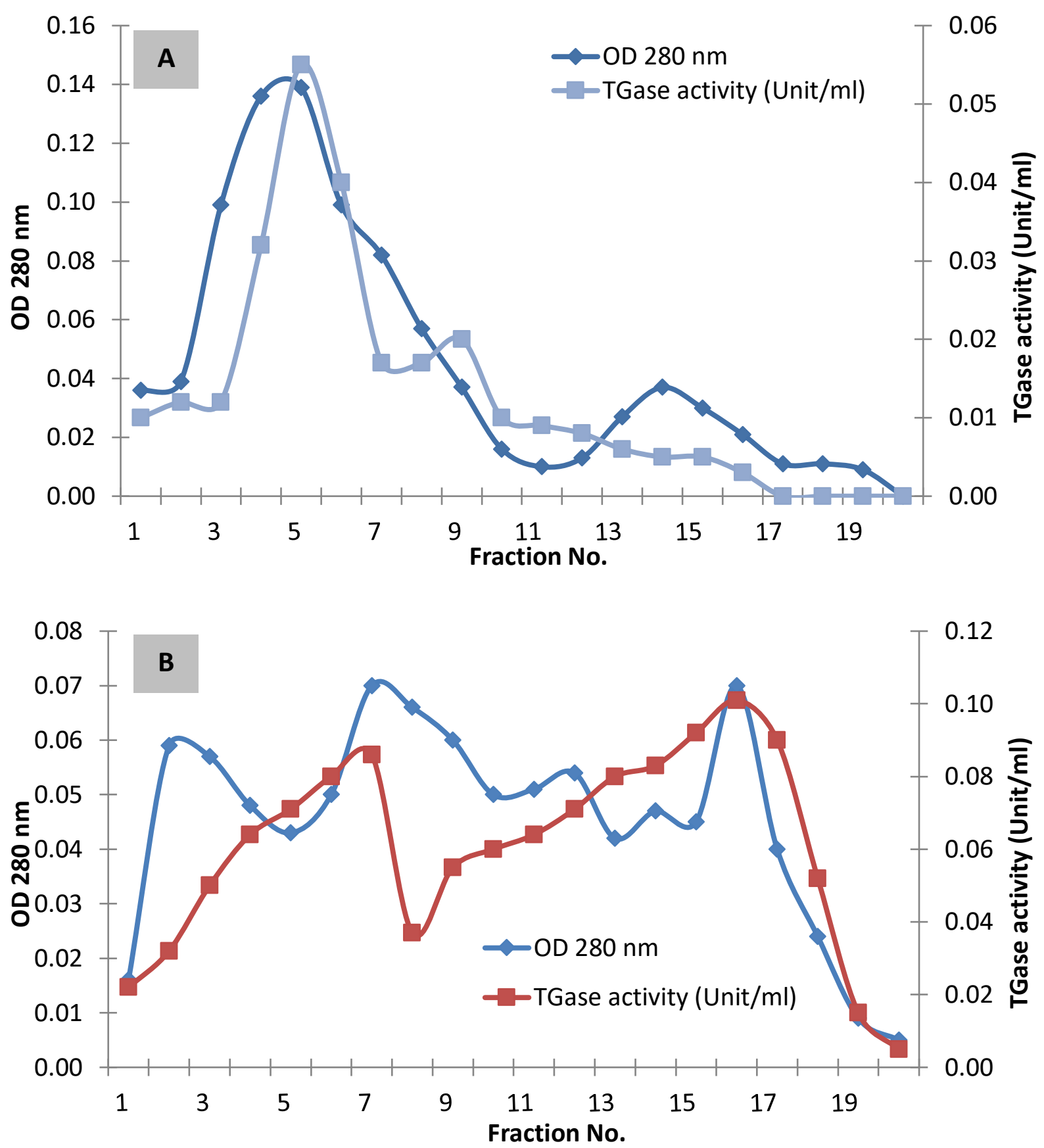

Figure 6. Size exclusion column chromatography on Sephadex G-100 of TGase from Bacillus cereus NRC 215 and BCrif5. (A, wild strain; B, mutant strain).

Table 7. Purification of TGase from mutant type of Bacillus cereus NRC215.

\begin{tabular}{l|c|c|c|c|c} 
Purification step & $\begin{array}{c}\text { Total TGase activity } \\
(\mathbf{U})\end{array}$ & $\begin{array}{c}\text { Total protein } \\
(\mathbf{m g})\end{array}$ & $\begin{array}{c}\text { Specific activity } \\
\text { (U/mg protein) }\end{array}$ & $\begin{array}{c}\text { Recovery } \\
(\boldsymbol{\%})\end{array}$ & $\begin{array}{c}\text { Purification } \\
\text { fold }\end{array}$ \\
\hline Crude extract & 5.92 & 0.92 & 6.43 & 100 & 1.00 \\
\hline ASP & 3.30 & 0.50 & 6.60 & 55.74 & 1.03 \\
\hline IEX & 2.58 & 0.36 & 7.17 & 43.58 & 1.12 \\
\hline SEC & 2.05 & 0.25 & 8.20 & 34.63 & 1.28
\end{tabular}

Recovery $=$ Total activity of purified enzyme/Total activity of crude enzyme X 100; Purification fold= Specific activity of purified enzyme/Specific activity of crude enzyme; ASP, Ammonium sulfate precipitation; IEX, Ion exchange chromatography; SEC, Size exclusion column chromatography. 
However, the optimal reaction temperature of TGase was varied with their sources; thus, the recorded optimal temperature of TGase from the selected strain Bacillus cereus NRC215 was lower than microbial TGase from Streptoverticillium mobaraense and plant TGase from rosemary (Rosmarinus officinalis L.), $\left(55^{\circ} \mathrm{C}\right)$ [51,12]; as well as microbial TGase from both Streptoverticillium ladakanu and Bacillus subtilis which recorded at $60{ }^{\circ} \mathrm{C}[52,53]$.

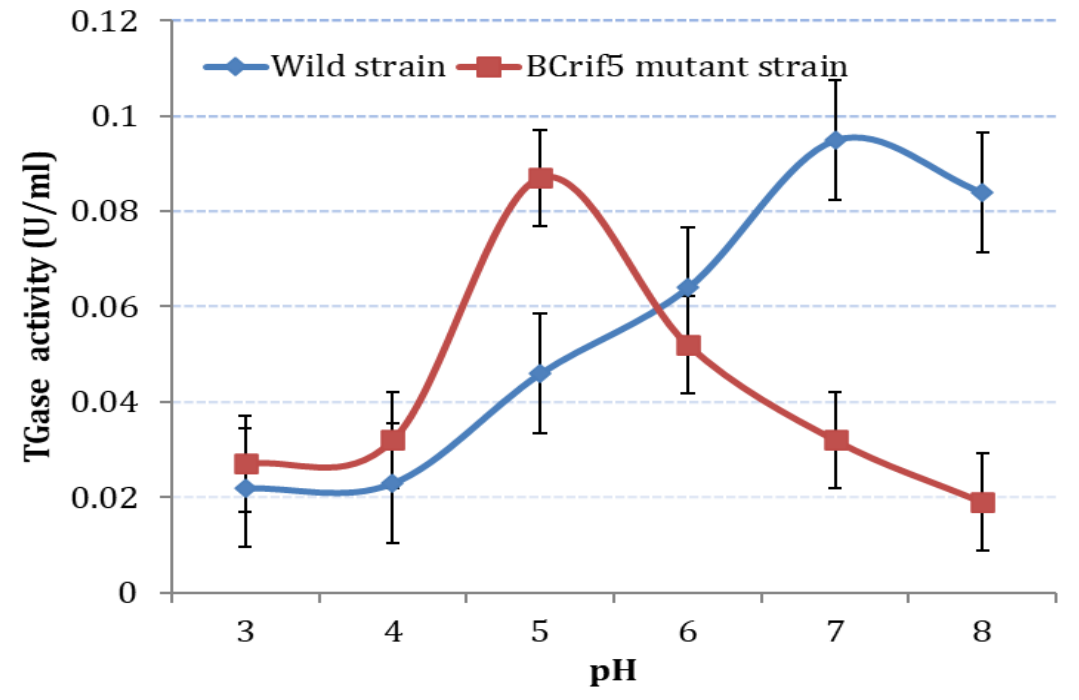

Figure 7. Optimum pH of TGase from the wild-type of Bacillus cereus NRC215 and BCrif5.

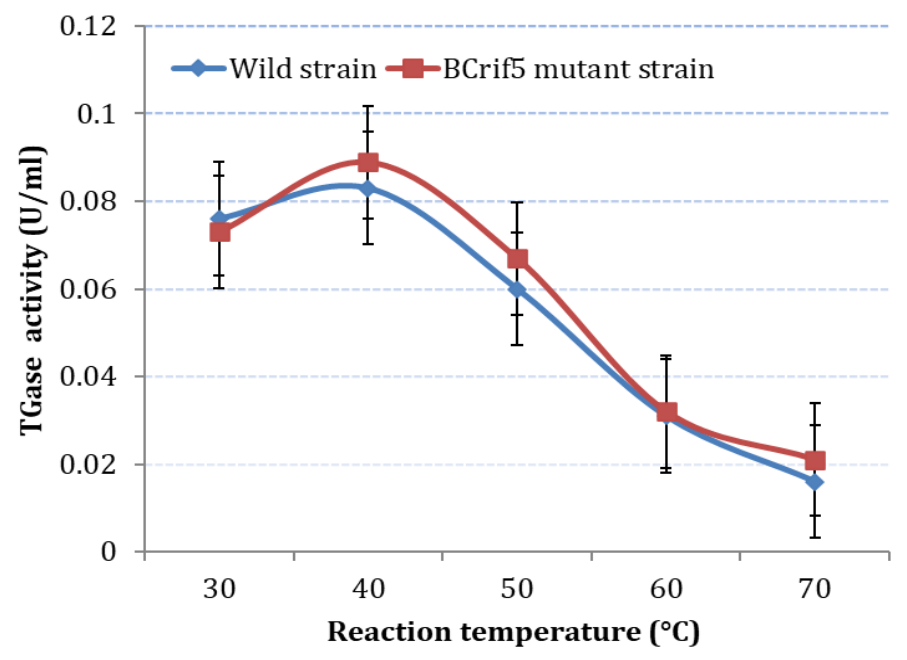

Figure 8. Temperature profile of TGase from the wild-type of Bacillus cereus NRC215 and BCrif5.

3.7.3. Metal ions susceptibility of TGase.

Figure 9 depicts the metal ions susceptibility of TGase from Bacillus cereus NRC215 in both wild and mutant (BCrif5) types. TGase activity from Bacillus cereus NRC215 slightly activated by $\mathrm{Ca}^{+2}$ ions (101.25 and $103.53 \%$ ), suggesting that the enzyme is calciumindependent for both wild and mutant strain types, respectively. It means that $\mathrm{Ca}^{+2}$ ions are not bound to the binding site of Bacillus cereus NRC215 TGase molecule, resulting in no conformational changes of its activity. This finding follows bacterial TGase from Streptoverticillum sp., Bacillus sp. [54,16], horseshoe crab TGase [55], bovine liver TGase [14], soybean and rosemary TGase [48,12]. Figure 9 presented that TGase was not inhibited by $\mathrm{Na}^{+}, \mathrm{Mn}^{+2}, \mathrm{Mg}^{+2}$, and $\mathrm{Zn}^{+2}$, where its residual activity ranges from 93.75 to $104.71 \%$. Also, Bacillus cereus NRC215 TGase was activated by $\mathrm{Ba}^{+2}$ (102.50 for wild and 107.06 for mutant 
BCrif5, Figure 9 agrees with TGase from microbial sources $[52,48,44]$. On the other hand, TGase from Bacillus cereus NRC215 was inhibited by $\mathrm{Cu}^{+2}(30 \%$ and $22.35 \%)$ and slightly inhibited by $\mathrm{Fe}^{+3}(12.5 \%$ and $9.41 \%)$ for wild and mutant strain types, respectively. It was speculated that the concentrations of $\mathrm{Fe}^{+3}$ are too low to induce proper conformational changes for the catalytic reaction of the TGase molecule [46]. These findings are in agreement with those reported by De Barros Soares et al. (2003) [48] and Sorde and Ananthanarayan (2019) [16].

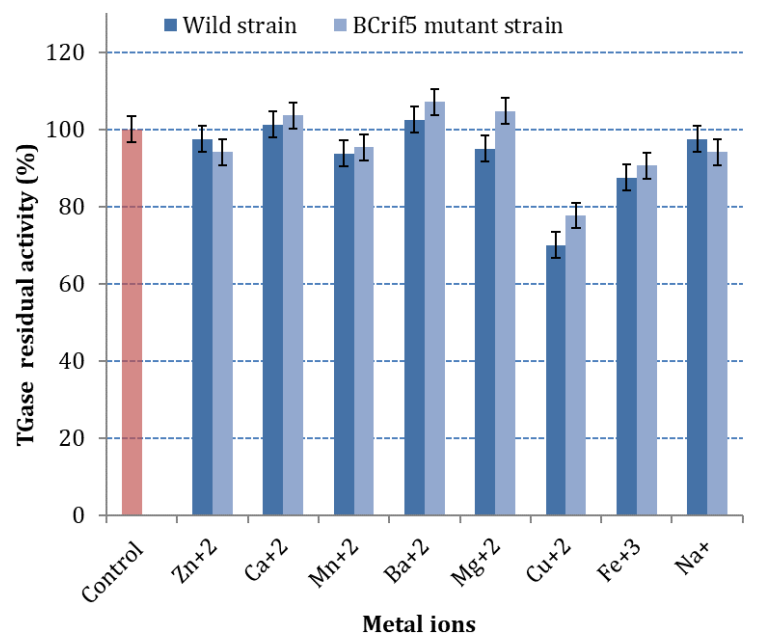

Figure 9. Metal ions susceptibility of TGase from wild-type of Bacillus cereus NRC215 and BCrif5.

\section{Conclusions}

It could be concluded that Bacillus cereus NRC215 is a promising strain for TGase production. Mutational genetics, for example, UV mutagenesis, proved its efficacy in TGase yield improvement as well as change in enzyme properties in the resulted RIF-resistant mutant. Also, The ISSR PCR is the most effective tool to differentiate between wild-type strain (Bacillus cereus NRC215) and its mutants. Moreover, the purification of TGase using ASP, IEX, and SEC showed good enzyme recovery in the final step. The optimal reaction condition of the purified TGase is suitable for the food industry.

\section{Funding}

This research was funded by National Research Centre (NRC, Egypt) under research grant number 12020214.

\section{Acknowledgments}

This research has no acknowledgment.

\section{Conflicts of Interest}

The authors declare no conflict of interest. The funders had no role in the study's design, in the collection, analyses, or interpretation of data, in the writing of the manuscript, or in the decision to publish the results.

\section{References}


1. Mostafa, H.S. Microbial transglutaminase: An overview of recent applications in food and packaging. Biocatalysis and Biotransformation 2020, 38, 161-177, https://doi.org/10.1080/10242422.2020.1720660.

2. Santhi, D.; Kalaikannan, A.; Malairaj, P.; Arun Prabhu, S. Application of microbial transglutaminase in meat foods: A review. Crit Rev Food Sci Nutr 2017, 57, 2071-2076, https://doi.org/10.1080/10408398.2014.945990.

3. Miwa, N. Innovation in the food industry using microbial transglutaminase: Keys to success and future prospects. Analytical Biochemistry 2020, 597, https://doi.org/10.1016/j.ab.2020.113638.

4. Zhang, D.; Zhu, Y.; Chen, J. Microbial Transglutaminase Production: Understanding the Mechanism. Biotechnology and Genetic Engineering Reviews 2009, 26, 205-222, https://doi.org/10.5661/bger-26-205.

5. Martins, I.M.; Matos, M.; Costa, R.; Silva, F.; Pascoal, A.; Estevinho, L.M.; Choupina, A.B. Transglutaminases: recent achievements and new sources. Applied Microbiology and Biotechnology 2014, 98, 6957-6964, https://doi.org/10.1007/s00253-014-5894-1.

6. Ibrahim, O.; Glibowski, P.; Nour, M.; El-Hofi, M.; El-Tanboly, E.; Abd-Rabou, N. Effect of Rosemary transglutaminase on yoghurt fortified with Whey protein isolate. Acta Sci. Pol. Technol. Alim. 2017, 67, 265274, https://doi.org/10.1515/pjfns-2016-0020.

7. Doti, N.; Caporale, A.; Monti, A.; Sandomenico, A.; Selis, F.; Ruvo, M. A recent update on the use of microbial transglutaminase for the generation of biotherapeutics. World Journal of Microbiology and Biotechnology 2020, 36, https://doi.org/10.1007/s11274-020-02829-y.

8. Chen, R.-N.; Ho, H.-O.; Sheu, M.-T. Characterization of collagen matrices cross-linked using microbial transglutaminase. Biomaterials 2005, 26, 4229-4235, https://doi.org/10.1016/j.biomaterials.2004.11.012.

9. Kamiya, N.; Doi, S.; Tominaga, J.; Ichinose, H.; Goto, M. Transglutaminase-Mediated Protein Immobilization to Casein Nanolayers Created on a Plastic Surface. Biomacromolecules 2005, 6, 35-38, https://doi.org/10.1021/bm0494895.

10. Wang, L.; Yu, B.; Wang, R.; Xie, J. Biotechnological routes for transglutaminase production: Recent achievements, perspectives and limits. Trends in Food Science \& Technology 2018, 81, 116-120, https://doi.org/10.1016/j.tifs.2018.09.015.

11. Ogilvie, O.; Roberts, S.; Sutton, K.; Larsen, N.; Gerrard, J.; Domigan, L. The use of microbial transglutaminase in a bread system: A study of gluten protein structure, deamidation state and protein digestion. Food Chemistry 2021, 340, https://doi.org/10.1016/j.foodchem.2020.127903.

12. Akbari, M.; Razavi, S.H.; Kieliszek, M. Recent advances in microbial transglutaminase biosynthesis and its application in the food industry. Trends in Food Science \& Technology 2021, 110, 458-469, https://doi.org/10.1016/j.tifs.2021.02.036.

13. Aloisi, I.; Distefano, G.; Antognoni, F.; Potente, G.; Parrotta, L.; Faleri, C.; Gentile, A.; Bennici, S.; Mareri, L.; Cai, G.; Del-Duca, S. Temperature dependent compatible and incompatible pollen-style interactions in Citrus clementina hort. ex Tan. Show different transglutaminase features and polyamine pattern. Front. Plant Sci. 2020, 11, https://doi.org/10.3389/fpls.2020.01018.

14. Razavian, S.M.H.; Kashfi, A.; Khoshraftar, Z. Purification of bovine liver transglutaminase by gel filtration. Applied Biological Chemistry 2020, 63, https://doi.org/10.1186/s13765-020-0490-9.

15. Ando, H.; Adachi, M.; Umeda, K.; Matsuura, A.; Nonaka, M.; Uchio, R.; Tanaka, H.; Motoki, M. Purification and Characteristics of a Novel Transglutaminase Derived from Microorganisms. Agricultural and Biological Chemistry 1989, 53, 2613-2617, https://doi.org/10.1080/00021369.1989.10869735.

16. Sorde, K.L.; Ananthanarayan, L. Isolation, screening, and optimization of bacterial strains for novel transglutaminase production. Prep. Biochem. Biotechnol. 2019, 49, 64-73, https://doi.org/10.1080/10826068.2018.1536986.

17. Shafique, T.; Shafique, J.; Zahid, S.; Kazi, M.; Alnemer, O.; Ahmad, A. Screening, selection and development of Bacillus subtilis apr-IBL04 for hyper production of macromolecule alkaline protease. Saudi Journal of Biological Sciences 2021, 28, 1494-1501, https://doi.org/10.1016/j.sjbs.2020.11.079.

18. Rakib, K.; Nain, Z.; Ahammed, B.; Karim, M. Developing Pseudomonas aeruginosa mutants with hyperproteolytic activity through UV mutagenesis and characterization for optimized production. 2020, 3, 135142, https://doi.org/10.5455/jabet.2020.d118.

19. Chandra, P.; Enespa; Singh, R.; Arora, P.K. Microbial lipases and their industrial applications: a comprehensive review. Microbial Cell Factories 2020, 19, https://doi.org/10.1186/s12934-020-01428-8.

20. Ochi, K.; Hosaka, T. New strategies for drug discovery: activation of silent or weakly expressed microbial gene clusters. Applied Microbiology and Biotechnology 2013, 97, 87-98, https://doi.org/10.1007/s00253-0124551-9.

21. Ochi, K.; Tanaka, Y.; Tojo, S. Activating the expression of bacterial cryptic genes by rpoB mutations in RNA polymerase or by rare earth elements. Journal of Industrial Microbiology and Biotechnology 2014, 41, 403414, https://doi.org/10.1007/s10295-013-1349-4.

22. Mohanty, P.S.; Bansal, A.K.; Naaz, F.; Patil, S.A.; Arora, M.; Singh, M. Dominant marker (inter-simple sequence repeat-polymerase chain reaction) versus codominant marker (RLEP-polymerase chain reaction) for laboratory diagnosis of leprosy: A comparative evaluation. International Journal of Mycobacteriology 2020, 9, 18-23, https://doi.org/10.4103/ijmy.ijmy_190_19. 
23. Mint Abdelaziz, S.; Medraoui, L.; Alami, M.; Pakhrou, O.; Makkaoui, M.; Ould Mohamed Salem Boukhary, A.; Filali-Maltouf, A. Inter simple sequence repeat markers to assess genetic diversity of the desert date (Balanites aegyptiaca Del.) for Sahelian ecosystem restoration. Scientific Reports 2020, 10, https://doi.org/10.1038/s41598-020-71835-9.

24. Folk, J.E.; Cole, P.W. Identification of a functional cysteine essential for the activity of guinea pig liver transglutaminase. The Journal of biological chemistry 1966, 241, 3238-3240.

25. Bradford, M.M. A rapid and sensitive method for the quantitation of microgram quantities of protein utilizing the principle of protein-dye binding. Analytical Biochemistry 1976, 72, 248-254, https://doi.org/10.1016/0003-2697(76)90527-3.

26. Zemb, O.; Achard, C.S.; Hamelin, J.; De Almeida, M.-L.; Gabinaud, B.; Cauquil, L.; Verschuren, L.M.G.; Godon, J.-J. Absolute quantitation of microbes using 16S rRNA gene metabarcoding: A rapid normalization of relative abundances by quantitative PCR targeting a 16S rRNA gene spike-in standard. MicrobiologyOpen 2020, 9, 1-19, https://doi.org/10.1002/mbo3.977.

27. Olukunle, O.F.; Ayodeji, A.O.; Akinloye, P.O. Carboxymethyl Cellulase (CMCase) from UV-irradiation Mutated Bacillus cereus FOA-2 cultivated on Plantain (Musa parasidiaca) Stalk-based Medium: Production, Purification and Characterization. Scientific African 2021, 11, https://doi.org/10.1016/j.sciaf.2020.e00691.

28. Williams, J.G.; Kubelik, A.R.; Livak, K.J.; Rafalski, J.A.; Tingey, S.V. DNA polymorphisms amplified by arbitrary primers are useful as genetic markers. Nucleic acids research 1990, 18, 6531-6535, https://doi.org/10.1093/nar/18.22.6531.

29. Sneath, P.H.A.; Sokal, R.R. Numerical Taxonomy. Freeman, San Francisco, 1973.

30. Colowick, S.P.; Kaplan, N. Methods in enzymology. Volume 1. Academic Press New York; 1955.

31. SAS Institute Inc. SAS User's Guide statistics. Ver. 8, SAS Inst. Cary, NC, USA; 1999.

32. Vogler, A.J.; Busch, J.D.; Percy-Fine, S.; Tipton-Hunton, C.; Smith, K.L.; Keim, P. Molecular analysis of rifampin resistance in Bacillus anthracis and Bacillus cereus. Antimicrobial agents and chemotherapy 2002, 46, 511-513, https://doi.org/10.1128/AAC.46.2.511-513.2002.

33. Sinha, P.; Srivastava, G.N.; Tripathi, R.; Mishra, M.N.; Anupurba, S. Detection of mutations in the rpoB gene of rifampicin-resistant Mycobacterium tuberculosis strains inhibiting wild type probe hybridization in the MTBDR plus assay by DNA sequencing directly from clinical specimens. BMC Microbiology 2020, 20, https://doi.org/10.1186/s12866-020-01967-5.

34. Ochi, K. From microbial differentiation to ribosome engineering. Biosci. Biotechnol. Biochem. 2007, 6, 13731386, https://doi.org/10.1271/bbb.70007.

35. Funane, K.; Tanaka, Y.; Hosaka, T.; Kiriko, M.; Miyazaki, D.; YuhShiwa, S.; Takashi, I.; Kasahara, K.; Fujita, N.; Yoshikawa, H.; Yoshikazu, Hiraga, Y.; Ochic, K. Combined drug resistance mutations substantially enhance enzyme production in Paenibacillus agaridevorans. J. Bacteriol. 2018, 200, 1-18, https://doi.org/10.1128/JB.00188-18.

36. Diep, T.B.; Thom, N.T.; Sang, H.D.; Binh, N.V.; An, T.X.; Thao, H.P.; Duong, P.D.; Quynh, T.M.; Thuan, T.B.; Lan, V.T. Study on enhancement protease-producing of bacillus subtilis by combining ribosome engineering and gamma irradiation. The Annu. Rep. 2016, 16, 173-182.

37. Tanaka, Y.; Kasahara, K.; Hirose, Y.; Murakami, K.; Kugimiya, R.; Ochi, K. Activation and products of the cryptic secondary metabolite biosynthetic gene clusters by rifampin resistance (rpoB) mutations in actinomycetes. J. Bacteriol. 2013, 195, 2959-2970, https://doi.org/10.1128/JB.00147-13.

38. Perkins, A.E.; Wayne, L.; Nicholson, W.L. Uncovering New Metabolic Capabilities of Bacillus subtilis using Phenotype Profiling of rifampin-resistant rpoB Mutants. J. Bacteriol. 2008, 190, 807-814, https://doi.org/10.1128/JB.00901-07.

39. Akramipour, N.; Abdollahi, M.; Taghavi, S.M.; Rezaei, R. Genetic diversity of soft rot strains of Pectobacterium, isolated from different hosts, using ISSR marker. Archives of Phytopathology and Plant Protection 2017, 50, 789-801, https://doi.org/10.1080/03235408.2017.1384195.

40. Verma, J P.; Jaiswal, D.K.; Krishna, R.; Prakash, S.; Yadav, J.; Singh, V. Characterization and screening of thermophilic bacillus strains for developing plant growth promoting consortium from hot spring of Leh and Ladakh region of India. Front. Microbiol. 2018, 9, 1-13, https://doi.org/10.3389/fmicb.2018.01293.

41. Goldsmith, L.A.; Martin, G.M. Human epidermal, transglutaminase. J. Invest. Dermatol. 1995, 80, $316-321$.

42. Kwak, S.J.; Kim, S.Y.; Kim, Y.S.; Song, K.Y.; Kim, I.G.; Park, S.C. Isolation and characterization of brainspecific transglutaminases from rat. Experimental \& molecular medicine 1998, 30, 177-185, https://doi.org/10.1038/emm.1998.26.

43. Gerber, U.; Jucknischke, U.; Putzien, S.; Fuchsbauer, H.L. A rapid and simple method for the purification of transglutaminase from Streptoverticillium mobaraense. Biochem. J. 1994, 299, 825-829, https://dx.doi.org/10.1042\%2Fbj2990825.

44. Cui, L.; Du, G.; Zhang, D.; Liu, H.; Chen, J. Purification and characterization of transglutaminase from a newly isolated Streptomyces hygroscopicus. Food Chemistry 2007, 105, 612-618, https://doi.org/10.1016/j.foodchem.2007.04.020.

45. Kobayashi, K.; Suzuki, S.; Izawa, Y.; Yokozeki, K.; Miwa, K.; Yamanaka, S.. Transglutaminase in Sporulating Cells of Bacillus subtilis. J. Gen. Appl. Microbiol. 1998, 44, 85-91, https://doi.org/10.2323/jgam.44.85. 
46. Worratao, A.; Yongsawatdigul, J. Purification and characterization of transglutaminase from tropical tilapia (Oreochromis niloticus). Food Chem. 2005, 93, 651-658, https://doi.org/10.1016/j.foodchem.2004.09.044.

47. Muley, A.B.; Chaudhari, S.A.; Singhal, R.S. Non-covalent conjugation of cutinase from Fusarium sp. ICT SAC1 with pectin for enhanced stability: Process minutiae, kinetics, thermodynamics and structural study. International Journal of Biological Macromolecules 2017, 102, 729-740, https://doi.org/10.1016/j.ijbiomac.2017.04.072.

48. De Barros Soares, L.H.; Assmann, F.; Záchia Ayub, M.A. Purification and properties of a transglutaminase produced by a Bacillus circulans strain isolated from the Amazon environment. Biotechnology and Applied Biochemistry 2003, 37, 295-299, https://doi.org/10.1042/BA20020110.

49. Kang, H.; Cho, Y.D. Purification and properties of transglutaminase from soybean (Glycine max) leaves. Biochem.Biophys. Res. Commun.1996, 223, 288-292, https://doi.org/10.1006/bbrc.1996.0886.

50. de Souza, C.F.V.; de Matos, G.S.; Flores, S.H.; Ayub, M.A.Z. Environmental effects on transglutaminase production and cell sporulation in submerged cultivation of Bacillus circulans. Appl. Biochem. Biotechnol. 2009, 158, 302-312, https://doi.org/10.1007/s12010-008-8338-5.

51. Lu, S.Y.; Zhou, N. D.; Tian, Y. P.; Chen, J. Purification and properties of transglutaminase from Streptoverticillium mobaraense. J. Food Biochem. 2003, 27, 109-126, https://doi.org/10.1111/j.17454514.2003.tb00270.x.

52. Ho, M.L.; Leu, S.Z.; Hsieh, J.F.; Jiang, S.T. Technical Approach to Simplify the Purification Method and Characterization of Microbial Transglutaminase Produced from Streptoverticillium ladakanum. Journal of Food Science 2000, 65, 76-80, https://doi.org/10.1111/j.1365-2621.2000.tb15959.x.

53. Suzuki, S.i.; Izawa, Y.; Kobayashi, K.; Eto, Y.; Yamanaka, S.; Kubota, K.; Yokozeki, K. Purification and Characterization of Novel Transglutaminase from Bacillus subtilis Spores. Bioscience, Biotechnology, and Biochemistry 2000, 64, 2344-2351, https://doi.org/10.1271/bbb.64.2344.

54. Kanaji, T.; Ozaki, H.; Takao, T.; Kawajiri, H.; Ide, H.; Motoki, M.; Shimonishi, Y. Primary structure of microbial transglutaminase from Streptoverticillium sp. Strain s-8112. J. Biol. Chem. 1993, 268, 1156511572.

55. Tokunaga, F.; Iwanaga, S. Horseshoe crab transglutaminase. Meth. Enzymol. 1993, 223, 378-388, https://doi.org/10.1016/0076-6879(93)23059-V. 